\title{
FROM THIRD WORLD TO FIRST WORLD: LAW AND POLICY IN SINGAPORE'S URBAN TRANSFORMATION \& INTEGRATION
}

\author{
EUGENE KB TAN \\ School of Law \\ Singapore Management University \\ Email: eugene@smu.edu.sg
}

\begin{abstract}
The physical transformation of a colonial backwater city, Singapore, in one generation has been described as a feat of urban planning, renewal, and development. Less studied is the political will of the government to create a thriving city fit for purpose. Even less studied is the role of law that provides the powerful levers for the rapid and deepseated changes to the urban landscape in Singapore. In this regard, the mindset shift that accompanied the massive urban transformation has facilitated a national psyche that embraces the material dimension of progress, for which urban renewal is not just a mere indicator but also a mantra for the fledgling nation-state desirous of change as a mark of progress. This essay examines the multi-faceted role of law in undergirding urban planning, policy, and development in Singapore. Rather than just providing a focus on specific laws that enables the government to shape the processes of urban redevelopment, the essay argues that these laws have to be understood within the context of "urban redevelopment pragmatism" in which pragmatism is as much a planning ideology as it is a driver of urban change and renewal. Furthermore, this planning pragmatism, very much mission-oriented towards national goals, has become a potent source of political and performance legitimacy for the ruling People's Action Party. The legal regime that provided the wherewithal for urban renewal, economic activity, water quality management, and spatial integration of a polyglot society is now being reconfigured for the urgent aspiration of becoming a global city and a smart nation. The essay also considers the limitations to this planning and redevelopment pragmatism, and how the rapid urban change has somewhat enervated the urban heritage and contributed to a weakening of the collective memory of change amid continuity.
\end{abstract}

Keywords: urban planning law and policy, Singapore, social integration

ingapore's physical transformation in one generation from a colonial Sbackwater to an aspiring global city has often been described as a feat of urban planning, renewal, and development. While the massive transformation was clearly inscribed in the physical landscape, these physical changes also paved the way for economic, social and cultural transformation as well, all in the name of nation-building. In a mere fifty years since independence was thrust upon it, Singapore's much-envied success embodies the criticality of urban planning in the transformation of the environment in the perpetual endeavor to overcome the constraints imposed by nature and by geopolitics.

It is trite that change is a constant. However, change is an existential imperative for Singapore. Singapore's physical landscape continues to 
change relentlessly, albeit with predictable routineness, even after half a century of rapid physical development. This will continue with the population roadmap to year 2030 embodied in the A Sustainable Population for a Dynamic Singapore White Paper. ${ }^{1}$ Already one of the world's most densely populated cities at 5.8 million people in Singapore's 700-odd square kilometers of landmass at the tip of the Malaysian peninsula, urban planners are making and executing plans that will enable the citystate, if need be, to house 6.9 million people by 2030. The government has taken pains to emphasize that enabling 6.9 million people to live in Singapore is a planning parameter, and not a population target.

"Bending" the physical landscape to the human's will is an integral, if somewhat neglected, part of the grand narrative of refusing to accept the geographical fate imposed upon Singapore. Due to severe land size limitations, Singapore grew upwards, sideways, and now, increasingly, downwards. ${ }^{2}$ Land reclamation was embarked upon to meet its needs for a growing population with even larger dreams and aspirations. Singapore continues to be constrained by its size given the limits of land reclamation. However, 'size is not destiny' is a clarion call for policy makers. The lack of water sufficiency, in which most of the raw water was imported from its neighbor, Malaysia, drove the obsession to create advanced water technology for potable "Newater" out of sewage and waste-water. ${ }^{3}$ Landfills were offshored, which in turn created a putative land mass with a new environment with rich, vibrant biodiversity. ${ }^{4}$ Today, underground granite caverns are being exploited for a variety of uses to overcome the limits to building sideways and upwards. ${ }^{5}$

\footnotetext{
National Population and Talent Division (2013), Population White Paper: A Sustainable Population for a Dynamic Singapore. Retrieved from https://www.strategygroup.gov.sg/mediacentre/population-white-paper-a-sustainable-population-for-a-dynamic-singapore [accessed 2 June 2020].

2 Singapore is already reaching its limits with land reclamation is concerned. As its seaport is integral to Singapore's position as a leading transport and logistics hub, land reclamation cannot reduce the already limited sea lanes of communication. On vertical growth and the use of layered space to create additional urban space, see Wong G. K.M. (2004), 'Vertical Cities as a Solution for Land Scarcity: The Tallest Public Housing Development in Singapore', 9 Urban Design International 17-30, and Heng C. K. \& Low B. L. (2009) 'New Asian Public Space: Layered Singapore,' 14 Urban Design International 231-246.

$3 \quad$ Yang W. \& Kuang J. Y. (2020), Water: From Scarce Resource to National Asset, Singapore: Centre for Liveable Cities. Retrieved from https://www.clc.gov.sg/docs/default-source/ urban-systems-studies/uss-water-revised.pdf [accessed 2 June 2020].

$4 \quad$ Ng M. F. C. (2012), Habitats in Harmony: The Story of Semakau Landfill, $2^{\text {nd }}$ edition, Singapore: National Environment Agency.

See also the transcript of Prime Minister Lee Hsien Loong's speech at the official opening of the Jurong Rock Caverns on 2 September 2014. Retrieved from http://www.pmo.gov.sg/mediarelease/transcript-prime-minister-lee-hsien-loongs-speech-official-opening-jurong-rock-caverns. For a quick account of the caverns, see http://www.straitstimes.com/the-big-story/explainers/ story/five-things-know-about-the-jurong-rock-caverns-20140902 [accessed 2 June 2020].
} 
These inspiring examples demonstrate the vision and power of political will, the harnessing of ingenuity and creativity, and deploying cutting-edge engineering and technology in the quest to be a global city. This is part and parcel of the goal to be relevant to the world. ${ }^{6}$ To be sure, these apparent defiant acts against nature would not have been possible had they not been foregrounded by the rapid economic progress that provided the financial wherewithal for financing the physical transformation. Without the sustained financial sinews, such seemingly far-fetched environmental audacity would not have been possible. ${ }^{7}$ Furthermore, the economic prosperity has allowed Singapore to access the state-of-the-art infrastructure, technology, and services that have facilitated larger efforts in preserving and enhancing her limited natural and man-made habitats and heritage. Clearly, Singapore's physical transformation demonstrates that the economy and the environment are not antithetical to each other.

Less studied is the political will of the government to create a thriving, cosmopolitan city. Even less studied is the role of law that provides powerful levers for the rapid and deep-seated changes to the urban landscape in Singapore. In this regard, the mindset shift that accompanied the massive urban transformation has facilitated a national psyche that embraces the material dimension of progress for which urban renewal is not just a mere indicator but also a mantra for the fledgling nation-state desirous of change as a mark of progress.

This essay examines the multi-faceted role of law in undergirding urban planning, policy, and development in Singapore. Rather than just providing a focus on specific laws that enabled the government to shape the processes of urban re-development, the essay argues that these laws have to be understood within the context of "urban redevelopment pragmatism" in which pragmatism is as much a planning ideology as it is a driver of urban change and renewal. Furthermore, this planning pragmatism, very much mission-oriented towards the attainment of national goals, has become a potent source of political legitimacy for the ruling People's Action Party (PAP). The legal regime that provided the expedited framework for urban renewal, economic activity, water

Guo R. (2018), Urban Redevelopment: From Urban Squalor to Global City, Singapore: Centre for Liveable Cities. Retrieved from https://www.clc.gov.sg/docs/default-source/urban-systemsstudies/uss-urbanredevelopment.pdf [accessed 2 June 2020].

Khoo T. C. (ed.) (2014), Financing a City: Developing Foundations for Sustainable Growth, Singapore: Centre for Liveable Cities. Retrieved from https://www.clc.gov.sg/docs/default-source/urbansystems-studies/uss-financing-a-city.pdf [accessed 2 June 2020]. See also Wu W.N. \& Chia J. (2017), Working with Markets: Harnessing Market Forces and Private Sector for Development. Singapore: Centre for Liveable Cities. Retrieved from https://www.clc.gov.sg/docs/default-source/urbansystems-studies/working-with-markets.pdf [accessed 2 June 2020]. 
quality management, and spatial integration of a polyglot society is now being reconfigured for the urgent aspiration of becoming a global city and the world's 'first smart nation'.

The short essay proceeds in three main parts. In the first part, it examines the foundational legal framework for urban planning and change through the Land Acquisition Act and the Planning Act. In the second part, the notion of urban redevelopment pragmatism as it pertains to Singapore is considered. This is explored through examining the Ethnic Integration Policy and the Singapore Permanent Resident Quota, demonstrating that physical transformation must complement social cohesion and development. In the third part, the essay argues that going forward, urban planning in Singapore must get away from the grips of the trade-offs discourse if a better balance is to be struck between the economic and non-economic dimensions of urban transformation. The essay then concludes by highlighting the limited universal relevance of Singapore's urban planning experience. Singapore's experience suggests that law and policy can make a difference in urban planning outcomes provided that implementation is efficient and effective, and underpinned by the rule of law.

\section{PROJECTING THE LONG ARM OF THE LAW: POSSIBILITIES, PROCESSES, AND POWER}

Law has played an important, if vastly understated, role in urban planning, development, and renewal. The power of legislation and a supportive legal regime to shape urban development possibilities, processes, and power is perhaps not well appreciated in the quotidian rush that urban growth encompasses. To be sure, the role and instrumentality of law is evident in areas such as zoning as part of a larger land use policy and the development of regulations to manage redevelopment.

Urban planning law, broadly conceived, as the full range of policies, laws and regulations that affect the urban environment, takes on greater importance as urbanization proceeds at breakneck pace especially in the developing world. For instance, 6.5 billion people or two-thirds of humanity will live and work in cities in $2050 . .^{9}$ Thus, the short- and

\footnotetext{
$8 \quad$ Tan B. \& Zhou Y. (2018), Technology and the City: Foundation for a Smart Nation, Singapore: Centre for Liveable Cities. Retrieved from https://www.clc.gov.sg/docs/default-source/ urban-systems-studies/uss-technology-and-the-city.pdf.

$9 \quad$ See Daalder I. (2015) 'An International Order of Cities Not States', Financial Times, 27 May, p. 7. This is also accompanied by the shift in the locus of economic activity to emerging markets and to the cities within these markets: see Dobbs R. (2015), 'The four global forces breaking all the trends', McKinsey Quarterly, April 2015. On the thesis that cities are not only sites of concentrated factor endowments but also of the ability to project power in the global system, see Leon J. K. (2015), 'The Role of Global Cities in Land Grabs,' 36 Third World Quarterly 257-273.
} 
long-term impact of urban law shapes not only the urban environment but also the relationships between stakeholders including individuals, corporations, developers, and interest groups..$^{10}$

There is no doubt that how urban planning laws are crafted and implemented affects the wellbeing of millions of people globally. While law making in this field is often technically driven in many respects, urban planning law is fundamentally a political and economic process that requires political and economic inputs, distinct from technical considerations, to the legal process. ${ }^{11}$

Singapore believes in the importance of law in promoting urban redevelopment and managing the challenges that comes with rapid and frequent urban renewal. ${ }^{12}$ In Singapore, the imprint for Singapore's urban planning is a veritable legacy of Singapore's British colonial past. The colonial past began with Stamford Raffles of the British East India Company founding of Singapore in January 1819. Raffles had the goal of turning Singapore into an entrepôt at the crossroads of East and West, and between the Indian and Pacific Oceans. The early vestiges of urban planning in Singapore can be traced to the British colonial period. But it was only upon independence that urban planning was applied throughout the island, paving the way for the physical transformation of Singapore.

The People's Action Party (PAP) government of independent Singapore made a conscious decision to exclude the constitutional right to property when the legislature promulgated the Singapore Constitution in December 1965. The Constitution Commission of 1966 also agreed with this stance, recognizing that Singapore was then only a small island of 225 square miles, and that more land would be required for public purposes as the population increased. As founding Prime Minister Lee Kuan Yew stated when moving the Constitution (Amendment) Bill,

10 For a study on Singapore's stakeholder engagement, see Khoo L.-M. (2018), Engaging Well, Forging Bonds: The Community as Stakeholders in Urban Development. Singapore: Centre for Liveable Cities. Retrieved from https://www.clc.gov.sg/docs/default-source/urban-systemsstudies/uss-engaging-well-website.pdf [accessed 2 June 2020].

11 Cf. Khublall N. \& Yuen B. (1991), Development Control and Planning Law in Singapore, Singapore: Longman Singapore. On urban planning generally, see Dale O. J. (1999), Urban Planning in Singapore: The Transformation of a City, Shah Alam: Oxford University Press; Wong T.C . \& Yap A. L. H. (2004), Four Decades of Transformation: Land Use in Singapore, 1960-2000, Singapore: Eastern University Press, and Yuen B. (ed.) (1998), Planning Singapore: From Plan to Implementation, Singapore: Singapore Institute of Planners.

12 For an in-depth discussion, see Toh E. \& Ee D.(2019), Rule of Law and Urban Development, Singapore: Centre for Liveable Cities. Retrieved from https://www.clc.gov.sg/docs/ default-source/urban-systems-studies/uss-rule-of-law-and-urban-development.pdf [accessed 2 June 2020]. 
“... once we spell out that no law shall provide for the compulsory acquisition or use of property without adequate compensation, we open the door for litigation and ultimately for adjudication by the Court on what is or is not adequate compensation". ${ }^{13}$

At the forefront of the government's effort to exert its executive might for the purpose of urban planning is the Land Acquisition Act. ${ }^{14}$ The Act was described by the then Law Minister as a "piece of socialist legislation". ${ }^{15}$ The Act had provided, inter alia, that no landowner should benefit from development which had taken place at public expense and, secondly, that the price paid on acquisition of land for public purposes should not be higher than what the land would have been worth had the government not carried out development generally in the area. ${ }^{16}$ This legislation enabled the government to pursue resolutely urban redevelopment, especially for public housing and industrialization purposes. ${ }^{17}$ Between 1959 and 1984, the government acquired a total of 177 square kilometers of land, which constituted about one-third of the total land area of Singapore then, with the bulk of the acquisitions taking place after 1967 enactment of the Land Acquisition Act. With the increase in acquired land parcels, the state became the biggest landowner by 1985 , owning 76.2 percent of the land in Singapore compared with 31 percent in $1949 .^{18}$

The combined effect of there being no constitutional right to the right to property and the Land Acquisition Act was that urban planning and change in Singapore could take place without protracted delays and with relative affordability to the public coffers. The imperative to urgently develop the economy meant that the initial urban planning was heavily geared towards economic development. This resulted in the

\footnotetext{
13 Singapore Parliament Reports, Vol. 24, Col. 435 (22 December 1965).

14 Cap. 152 (1985 Revised Edition).

15 Singapore Parliament Reports, Vol. 25, Col. 416 (26 October 1966) per Mr E W Barker.

16 Singapore Parliament Reports, Vol. 25, Col. 133 (22 June 1966) per Mr E W Barker.

17 The Land Acquisition Act was again amended in 1973 to fix the compensation amount for acquired land at the market value as at 30 November 1973 or at the date of gazette notification, whichever was lower. This, of course, caused tremendous unhappiness among landowners in later years whose properties were worth much more than 1973 prices. For a further analysis, see Khoo T. C. (ed.) (2014), Land Acquisition and Resettlement: Securing Resources for Development, Singapore: Centre for Liveable Cities. Retrieved fromhttps:// www.clc.gov.sg/docs/default-source/urban-systems-studies/uss-land-acquisition-andresettlement.pdf [accessed 2 June 2020].

18 Information obtained from 'Land Acquisition Act is Enforced', HistorySG. Retrieved from http://eresources.nlb.gov.sg/history/events/1f669eff-bc82-49d1-a27c-2624e4cab8c6 [accessed 2 June 2020]. See also Phang S. Y. (1996), 'Economic Development and the Distribution of Land Rents in Singapore: A Georgist Implementation,' 55 The American J. of Economics and Sociology 489-501.
} 
swift establishment of the Jurong industrial estate out of swamp lands on the western part of the island. On the social development front, the need to revamp public housing urgently necessitated massive urban renewal and change to accommodate a growing population. ${ }^{19}$

\section{URBAN PLANNING IN SINGAPORE ${ }^{20}$}

Given Singapore's land scarcity, urban planning in the citystate is geared towards optimizing the use of land resources for current and future generations of residents. Land has to be allocated for various competing uses such as housing, education, commerce, industry, transport, recreation and defense, as well as determining the development density for various locations within the island. The Urban Redevelopment Authority (URA), a statutory board under the Ministry of National Development, is the national authority for urban planning in Singapore. ${ }^{21}$ It is the primary agency responsible for administering the Planning Act and its subsidiary legislation. The Planning Act stipulates the regulatory regime governing the urban planning process and the development control system. ${ }^{22}$

Besides the URA, two other government statutory boards closely involved in the urban planning are the Housing and Development Board (HDB) and the JTC Corporation (JTC). As the lead agency in urban planning, the URA prepares the Concept Plan and the Master Plan, the two most influential and comprehensive framework plans that guide the physical development of Singapore. ${ }^{23}$ Under section 8(1) of the Planning Act, the URA has to review the Master Plan at least once in every 5 years. The URA submits a report of the National Development Minister together with proposals for amendments to the Master Plan. A schematic diagram of the planning process is appended below:

19 Kwek S. C. (2019), Resettling Communities: Creating Space for Nation Building, Singapore: Centre for Liveable Cities. Retrieved from https://www.clc.gov.sg/docs/default-source/ urban-systems-studies/uss-resettling-communities.pdf [accessed 2 June 2020].

20 See also Ooi G. L. (2004), Future of Space: Planning, Space and the City, Singapore: Eastern Universities Press.

21 The URA's mission is 'to make Singapore a great city to live, work and play in'. See Tan S. (1999), Home, Work, Play, Singapore: Urban Redevelopment Authority.

Cap. 232 (1998 Revised Edition).

The URA Concept Plan is a strategic land use and transportation plan that guides Singapore's development over the next 40-50 years. Reviewed every ten years, the Concept Plan ensures that there is sufficient land to meet long-term population and economic growth needs while providing a good quality living environment. The Master Plan is a statutory plan that guides development plans over the next 10 to 15 years. It translates the broad, long-term strategies of the Concept Plan into detailed plans for implementation by specifying the permissible land uses and densities. It is reviewed once every five years. Retrieved from https://www.ura.gov. sg/Corporate/Planning [accessed 2 June 2020]. 


\section{Concept Plan}

The Concept Plan is the strategic land use and transportation plan that guides Singapore's development over the next 40-50 years

\section{Master Plan}

The Master Plan translates the broad and long-term strategies of the Concept Plan into detailed plans for implementation over 10-15 years

\section{$\downarrow$}

\section{Implementation}

Through the Government Land Sales (GLS), state land is released for development

\section{URA's Development Control Group evaluates and} grants approval for development projects,

and ensure they are in line with planning strategies and guidelines

Figure 1: Urban planning process in Singapore

Given the competing, and sometimes conflicting, demands for scarce land resource, urban planning in Singapore requires a delicate balancing act. Urban planners have to take into account all the major land-use needs, including future ones. As the nation-state matures, urban planners will also have to reconcile the economic needs with the need to conserve the nation's natural and built heritage. ${ }^{24}$ This is the call for the urban planners, working with all relevant stakeholders, to be even-handed between competing needs and demands.

\section{URBAN REDEVELOPMENT PRAGMATISM}

For a resource-bereft city state, the political commitment to uplifting economic prospects of Singaporeans meant that pragmatism, not ideology, was the order of the day. There was no luxury of policy options. For Singapore, it was economic survival or its political demise as a sovereign nation-state. As Lee Kuan Yew remarked, "The mass of the people are not concerned with the legal and constitutional forms and niceties... As far as they are concerned,

Koolhaas R. had described Singapore as devoid of authenticity, where "even chaos is planned chaos". See his 1995 essay, 'The Singapore Songlines - Portrait of a Potemkin Metropolis,' in Koolhaas R. and Mau B., edited by Sigler J. (1995), Small, Medium, Large, Extra-Large: Office for Metropolitan Architecture, Rotterdam: O10 Publishers. 
... they did elect their own government in order that there might be a better world for them and their children". ${ }^{25}$ The mindset shift that accompanied the massive urban transformation has facilitated the evolution of a national psyche that embraces the material dimension of progress for which urban renewal is not just a mere indicator but also a mantra for the fledgling nation-state desirous of rapid change as a mark of progress.

In Singapore, it is clear that the legal regime made land acquisitions by the government as legally unchallenging as possible. The extensive powers to compulsorily acquire real estate in the name of progress was not only tolerated by Singaporeans but perhaps celebrated as a mark of the nationstate's determination to find its economic footing amid palpable doubts and fears that Singapore without the economic hinterland offered by peninsular Malaysia would be doomed. The government delivered on its economic promises resulting in its acquiring performance legitimacy and popular support from the people. ${ }^{26}$

Beyond the multi-faceted role of law in undergirding urban planning, policy, and development in Singapore, the legal regime is best appreciated as a manifestation of "urban redevelopment pragmatism" in which pragmatism is as much a planning ideology as it is a driver of urban change and renewal. Put simply, urban redevelopment pragmatism is premised on the basis that urban planning and redevelopment be driven by the simple criterion of what works. It is not inclined towards any particular urban planning theories but very much undergirded by the imperative to put in place what is necessary to get the job done. In this regard, it is very much ends-driven. ${ }^{27}$

In the Singapore context, the shared purpose of urban planning is to enable and ensure land use in Singapore is the vital substratum for economic growth. If inadequate land was provided for the needs of industry and public housing, then economic and social wellbeing was unattainable. The state's determined acquisition of large tracts of land was almost expected, if not demanded, as an aspect of efficient and effective governance.

Land, for a good part of Singapore's post-independence history, was primarily seen as factor of production, almost devoid of values. This steely pragmatism, initiated by the government and endorsed by large segments of the population, operated as a de facto planning paradigm and as a quasi-

\footnotetext{
$25 \quad$ Lee's speech at the Civil Service Political Study Center on 15 August 1959, in Han F. K. et al. (eds.) (1998), Lee Kuan Yew: The Man and His Ideas, Singapore: Times Editions, 318-319.

26 See, generally, Ng M. \& Choy C. P. (2018), Land Framework of Singapore: Building a Sound Land Administration and Management System, Singapore: Centre for Liveable Cities. Retrieved from https://www.clc.gov.sg/docs/default-source/urban-systems-studies/uss-land-framework-ofsingapore.pdf [accessed 2 June 2020].

27 See also Kwek M. L. (2004), 'Singapore: A Skyline of Pragmatism', in Bishop R. et al., (eds.), Beyond Description: Singapore Space Historicity, London: Routledge
} 
ideology. As an ideological force of sorts, pragmatism was the epitome of simplicity and sheer dogged determination: Its directive power lies in its doing things on the basis of what works. ${ }^{28}$

Singapore's urban planning is not just characterized by a disciplined land use policy. This aspect of urban planning can be willed into a place by coercive methods backed by the full force of law. What is also noteworthy of the Singapore development experience is how urban planning was also focused on the spatial integration of the polyglot population. This social dimension of urban planning was not an after-thought but very much an integral part of Singapore's urban planning and transformation. Housing a nation was very much also about ensuring that people of different races, religions, and languages found commonality in being Singaporean citizens and promoted multiracialism.

\section{Housing and Integrating a Putative Nation-State}

On gaining independence, many post-colonial societies faced the challenge of charting their national destinies in an inclusive approach to nation-building. Singapore has enjoyed relative ethnic harmony since its independence in 1965 and has been cited as a model for other post-colonial societies to emulate. "Racial and religious harmony" is enshrined as one of Singapore's five Shared Values, a putative national ideology, ${ }^{29}$ and is a cornerstone of Singapore's impressive transformation to a newly industrializing economy. Singapore's policy of "multiracialism", in which no race is privileged or disadvantaged by state laws, institutions and policies, has resulted in substantive constitutional and institutional engineering in the late 1980s to ensure the sustainability of ethnic stability and harmony in Singapore society. ${ }^{30}$ Singapore's population comprises about 75 per cent Chinese, 13 per cent Malay (the indigenous people), 9 per cent Indian, and 2 per cent "Others". ${ }^{31}$ Despite constituting 15 per cent of Singapore's population, geopolitics and history have given the Malay community (almost all of whom are Muslims) a significant influence that is disproportionate to their size. ${ }^{32}$

In order to house a burgeoning population, public housing was seen as a site to demonstrate the government's ability to deliver on its electoral promises. The PAP government had the goal of wanting to make every

28 On one aspect of Singapore's economic pragmatism, see Schein E. H. (1996), Strategic Pragmatism: The Culture of Singapore's Economic Development Board. Cambridge, MA: MIT Press.

29 The other four Shared Values are: Nation before community and society before self; family as the basic unit of society; community support and respect for the individual; consensus, not conflict. An accompanying discourse intimately connected with multiracialism is meritocracy.

From the 2000 population census. The generic 'Others' includes all other races not captured by the 'Chinese', 'Malay,' and 'Indian' racial classifications.

32 Singapore's closest neighbors are Malaysia and Indonesia, both of which have substantive Malay/Muslim populations. 
Singaporean a stakeholder. It envisaged making every family household own their public housing apartment. Today, almost 80 per cent of Singaporeans live in public housing with almost 90 per cent of these households owning their residential units.

However, the colonial experience (1819-1959) saw a divide-and-rule policy of the local population that was also accorded a spatial manifestation. Raffles, who was responsible for the British East Indian Company's acquisition of Singapore, was also the initial town planner. The "native populations" were housed in demarcated areas within the city. ${ }^{33}$ This meant that there were specific areas designated for the Chinese, the Malays, and the Indians.

The PAP government resolutely disbanded these racial enclaves when it came into power in 1959 after the British granted Singapore selfgovernment. ${ }^{34}$ Resettlement was a high priority policy agenda item as land use went through its initial rationalization and planning in the creation of a new society. New public housing estates, with modern amenities and sanitation, were planned and developed to house the resettled families.

The management of ethnic relations in Singapore extends to the careful micro-regulation of the spatial distribution of the races in the city-state. As discussed earlier, given that the vast majority of Singapore's population live in public Housing and Development Board (HDB) estates, this facilitated the PAP government's fulfillment of multiple political, economic and social goals, and lending credence to its performance legitimacy. Public housing was a key site of socialization, in similar ways that schools and national service were. People learned to live with others who were not like them. It was also hoped that these public housing estate dwellers will also understand and appreciate the beliefs, culture, values of Singaporeans of different backgrounds.

After the 1988 general election, the government articulated its concern over the formation of racial enclaves within public housing estates and explained the need for and implementation of the "Ethnic Integration Policy" (EIP). The EIP aims to promote racial harmony in public housing estates by formalistically creating ethnically integrated communities at the apartment block (micro-level) and neighborhood/precinct (macro-level) levels. It does this by mandating a racial composition that reflects the overall national situation. The EIP formalized and widened the scope of a longstanding rudimentary policy of deliberate, race-based quota system for

\footnotetext{
$33 \quad$ The term 'native populations' was Raffles' choice in describing the non-European populations who had settled in Singapore. See Buckley C. B. (1984), An Anecdotal History of Old Times in Singapore: From the Foundation of the Settlement on February $6^{\text {th }}, 1819$ to the Transfer to the Colonial Office on April 1 ${ }^{\text {st }}$, 1867, Singapore: Oxford University Press, 81-85.

34 Large-scale urban resettlement, which facilitated the break-up of colonial ethnic enclaves, was the norm in the first two decades after independence. See further Hill M. \& Lian K. F. (1995), The Politics of Nation Building and Citizenship in Singapore, London: Routledge, 113-139.
} 
spatial integration in public housing. Prior to the EIP's formal promulgation in 1989, the quota of Malays in any estate or new town was maintained at no more than 20 per cent.

The EIP operates in the following manner: On the primary market (apartment units purchased directly from the HDB), the HDB allocates new apartment units to eligible buyers on a first-come-first-served basis until the quota for each race is reached at either the apartment block and neighborhood levels (see Table 1 below). Once the quota is reached for any particular race, no more apartment units will be allocated to buyers of that race. The same principle is applied to the secondary (resale) market.

Sellers and buyers are free to enter into sale and purchase agreements as long as the relevant racial quota is not reached. However, a proposed sale would be prohibited if it caused any race to be further over-represented as a consequence of that transaction.

Table 1: EIP Public Housing Quotas

\begin{tabular}{|l|c|c|c|}
\hline \multicolumn{1}{|c|}{ Race } & $\begin{array}{c}\text { Neighborhood } \\
(\%)\end{array}$ & $\begin{array}{c}\text { Block } \\
(\%)\end{array}$ & $\begin{array}{c}\text { National Population (\%) } \\
\text { in Year 2000 }\end{array}$ \\
\hline Chinese & 84 & 87 & 76.8 \\
\hline Malay & 22 & 25 & 13.8 \\
\hline Indian/Others & 10 & 13 & 7.9 \\
\hline
\end{tabular}

Source: Parliamentary Debates Singapore (1989) and Singapore Population Census 2000

From a policy perspective, the EIP's impeccable and prudent objectives provide an effective but intrusive means of regulating the size and distribution of the races in each public housing estate, and throughout the entire city-state. The policy objective is to ensure that no particular race is disproportionately represented and, more importantly, that the minority races would not constitute the majority in any electoral district. This reduced potential for the manifestation of a racial card in elections has been advantageous to stable state of race relations in Singapore. ${ }^{35}$

The assessment of theEIP's effectivenessismixed. ${ }^{36}$ From the government's standpoint, the EIP has ensured that there is less "ethnic regrouping" in public housing estates. In 1989, 28 per cent of the 105 neighborhoods had at least one ethnic group that reached or exceeded its neighborhood limit. In September 2003, Parliament was informed that out of 165 neighborhoods,

$35 \quad$ Rodan G. (1996), 'Elections Without Representation: The Singapore Experience under the PAP', in Taylor R. H. (ed), The Politics of Elections in Southeast Asia. New York: Cambridge University Press, 61-89 at 75.

36 Chua B. H. (1997), Political Legitimacy and Housing: Stakeholding in Singapore, London, Routledge, 142-145. 
only 25 per cent were not "ethnically balanced". ${ }^{37}$ In contrast, the population's views of the EIP are more equivocal. ${ }^{38}$ In most instances, the EIP quotas affect most adversely the minorities since the pool of potential flat buyers, especially during a poor housing market, is reduced. ${ }^{39}$ Even if the EIP does not have a discriminatory intent, it certainly has a discriminatory effect as it affects the minorities most significantly, leading them to perceive the EIP as being discriminatory. Since the EIP's introduction, despite acknowledging the grievances and regular appeals by legislators to relax the harshness of the scheme's operation, the government is steadfastly against any attempt to relax the EIP on the grounds of the larger good of ethnic integration.

\section{Managing the Immigration Imperative}

In February 2013, Parliament approved the controversial Population White Paper, which paved the way for the government to draw up plans, as planning parameters, for Singapore to be home to 6.9 million people by 2030. Together with the Population White Paper, the government also released A High Quality Living Environment for All Singaporeans: Land Use Plan to Support Singapore's Future Population in January 2013.40 This was aimed to assuage concerns that Singapore could not manage the larger population given the longstanding concerns with the physical constraints. However, neither document raised the confidence level of the masses. Specifically, the planning parameter was widely interpreted instead as a population target. With the challenges posed by immigration, it remains to be seen if the population would be won over. Much will depend on whether the various policies, including urban planning, can work coherently to overcome the deep reservations.

Prior to the 2013 population roadmap, the government sought to integrate new immigrants into Singapore society, principally through its housing policies. In so doing, it drew inspiration from the Ethnic Integration Policy (EIP). To reiterate, the EIP's primary aim is to ensure that there is a balanced inter-racial mix in residential areas, promoting inter-racial interaction and preventing the formation of racial enclaves. Observing that new immigrants had a tendency to reside in precincts where other recent immigrants congregate, the government remains vigilant in preventing new citizens and PRs from forming enclaves of

\footnotetext{
$37 \quad$ Singapore Parliament Reports, Vol. 76, Col. 2859 (1 September 2003) per Minister for National Development Mah Bow Tan..

38 Eng L. A. (1995), Meanings of Multiethnicity: A Case Study of Ethnicity and Ethnic Relations in Singapore, Kuala Lumpur: Oxford University Press, 121-132.

39 Chih H. S. (2002) 'The Quest for a Balanced Ethnic Mix: Singapore's Ethnic Quota Policy Examined', 39 Urban Studies 1347-1374 at 1360-1364.

40 The report can be found at http://www.mnd.gov.sg/landuseplan/e-book/files/assets/basic-html/ index.html\#page1 [accessed 2 June 2020]. On the futuristic dimension of urban planning and architecture in Singapore, see Lim E. B. (2014) 'Future Island,' 28 Third Text 443-453, and Chang J. H. \& Winter T. (2015) 'Thermal Modernity and Architecture', 20 The Journal of Architecture 92-121.
} 
their own. Mindful that it is natural to congregate among those of one's own kind, the state is also acutely aware of the need not only for new immigrants to integrate into the mainstream but also for Singaporeans and new immigrants to interact and engage with each other.

In March 2010, the government introduced a separate quota, known as the Singapore Permanent Resident (SPR) Quota, for PRs buying resale flats to prevent them from forming enclaves in public housing estates. Thus, permanent residents seeking to purchase a resale HDB flat will have to meet both the SPR and the EIP quotas. However, the SPR quota applies only to non-Malaysian SPRs; Malaysian SPRs are not subjected to the SPR quota "in view of their close cultural and historical similarities with Singaporeans". "41

\begin{tabular}{|c|c|c|}
\hline \multirow{2}{*}{ Immigration Status } & \multicolumn{2}{|c|}{$\begin{array}{c}\text { Maximum proportion for } \\
\text { Non-Malaysian SPR Households }\end{array}$} \\
\cline { 2 - 3 } & Neighbourhood & Block \\
\hline Citizens & \multirow{2}{*}{ Not Applicable } & Not Applicable \\
\hline Malaysian SPRs & & $8 \%$ \\
\hline Non-Malaysian SPRs & $5 \%$ & \\
\hline
\end{tabular}

Dr Vivian Balakrishnan, then Minister of Community Development, Youth and Sports, had in 2009 put forth the philosophical underpinning for the integration of new immigrants:

Let me start by saying that this [integration] is a long-term, multi-faceted and complex challenge that all stakeholders in our society, and not just the Government, will have to take up. First, Singaporeans have to understand the need for immigrants and be comfortable with the social adjustments that are needed in order to maintain an open and welcoming society. We do so with our own enlightened self-interests in mind. Second, the new immigrants must subscribe to our core values of multi-racialism and meritocracy in a fair and just society. Third, we need to build more social bridges to connect these new Singaporeans to the already existing much larger pool of Singaporeans in order to build a larger united and cohesive community. The children of new immigrants must grow up and be indistinguishable from the children of local Singaporeans. That is the way we build a long-term united society. ... Both locals and newcomers must realise that integration is a two-way process and it does not come

$41 \quad$ Information obtained from the Housing and Development Board: http://www.hdb.gov.sg/ fi10/fi10321p.nsf/w/BuyResaleFlatEthnicIntegrationPolicy_EIP?OpenDocument [accessed 2 June 2020]. 
about by accident. Much effort and commitment will be required from all of us in order to make integration work, and I encourage newcomers to be proactive in learning about Singapore, widening their social circles, participating and contributing to the larger Singapore family. ${ }^{42}$

\section{GOING FORWARD}

For Singapore, the tension between the economy and the environment, broadly construed, will persist as an immutable fact of its existence. Urban planning has enabled Singapore to attain a high quality of urban living environment. Given the compactness of the island, Singapore had no choice but to make the best of the imperative of creating an optimal living environment, one that is attractive for living, working, and playing. This extended to making Singapore a "Garden City" and, subsequently, "a city in a garden". This involved a sustained effort since the early 1960s of treeplanting and the general greening of the island to soften the harsh effects of the "concrete jungle". ${ }^{43}$

Singapore, going forward, will have to demonstrate that it can sustain a symbiotic relationship between the economy and the environment, necessary for its overall wellbeing. In turn, and more importantly, this mindset can open new pathways to a dynamic future in which Singapore's progress and prosperity are in sync with its environment and rich heritage. ${ }^{44}$ It will also help the present connect with the past and the future as well in more ways than the economic dimension can. Here, urban planning going forward must place the accent on values as much as value.

Undergirding the story of Singapore's urban progress is the meticulous urban planning that has gone into the urban transformation process. Partly socialized by the change as modernization paradigm, Singaporeans have come to expect rapid changes in their lives even as they yearn for constancy and familiarity in their surroundings and lament the disappearing heritage both natural and man-made. The controversies over the demolition of the old landmark buildings, of cemeteries making way for new housing estates and roads, or even the angst and anger over the overall population policy with rapid immigration and how it affects Singapore's national identity continue to highlight if the balance between continuity and change has been properly struck. ${ }^{45}$

\footnotetext{
$42 \quad$ Singapore Parliament Reports, Vol. 86, Col. 1171 (23 November 2009).

43 See further Henderson J. C. (2013), 'Urban Parks and Green Spaces in Singapore', 18 Managing Leisure, 213-225.

44 Melic K. (2019), Past, Present and Future: Conserving the Nation's Built Heritage, Singapore: Centre for Liveable Cities. Retrieved from https://www.clc.gov.sg/docs/default-source/ urban-systems-studies/uss-conserving-the-nations-built-heritage.pdf [accessed 2 June 2020].

45 On cities needing a distinctive identity, see Bell D. A. \& Shalet A. de (2011), The Spirit of Cities: Why the Identity of a City Matters in a Global Age, Princeton, NJ: Princeton University Press.
} 
Co-existence of the economy and environment in urban planning is not enough as the competing demands grow. Co-existence signals living together despite fundamental disagreements. Embedded in co-existence is the language of trade-offs. And in Singapore's context, it is very often the economy that takes precedence. The environment seemingly exists at the behest of the economic imperatives.

In Singapore's next stage of urban planning, the economy and environment have to go beyond mere co-existence so that both dimensions are in harmony and aligned with each other. To see the economy and the environment as two separate spheres or as two distinct set of rights, interests, and power is a false dichotomy. Given the mantra of economic growth, the environment will be subordinated to the economy. In this scenario, tradeoffs are portrayed as inevitable and necessary for our survival. But must it be so? If the economy and the environment are seen as two sides of the same coin, then trade-offs will be seen as poor choices. The fact of the matter is that if we consciously look for trade-offs, they will be found.

The language of trade-offs can straitjacket the thinking of what needs to be done to attain the ideals of economic growth and environmental sustainability in urban planning. Such a language contains the grammar of domination (where one prevails over the other) and compromise (where both gives in to maintain harmony). But this means tension will be inherent in such a system. Perhaps in urban planning, the economy and the environment can operate as check and balance each other.

In short, a significant challenge facing Singapore in this regard is to develop the art of not making trade-offs, and that means striving to align the interests and needs of the economy and the environment in a holistic manner. This does not take away the necessity of making policy choices. But what it does is to avoid the propensity of looking at policy options in binary terms. In so doing, adverse impacts on the environment can be prevented in the quest for economic growth. At the same time, the search here where the economy and the environment are concerned is for balance - not a perfect equilibrium, it must be said. Otherwise, one dogma would be replaced by another dogma.

A balanced development recognizes that the economy and the environment is not a zero-sum proposition in urban planning. More than that, it recognizes that the imperatives of the economy and the environment may shift according to needs. It can prevent extreme pendulum swings in how development and growth is approached. Such a dynamic equilibrium and perspective of development encourages systemic resilience, adaptive capability, and societal responsiveness. This will heighten the quest for holistic solutions that will be exercise resourcefulness, creativity, and innovation while 
avoiding the mutually exclusive boundaries of what's economic and what's environmental.

If the economy trumps the environment more often than not, then policies - including strategies and interventions - will also likely ignore the troubling questions of unequal access to finance, land, and other resources. It also signals that the appropriate balance between the societal, community, and individual needs and concerns is not attained since a sticker price is attached to most things. ${ }^{46}$ At this stage of Singapore's nation-building, having had the benefit of rising incomes combined with sound environmental policies and institutions, Singapore is well-positioned to tackle both economic and environmental challenges in an integrated manner. It is also clear that Singapore cannot segment her policy considerations into water-tight compartments of the economy and the environment. In this connection, it is prudent for policy-makers to adopt the precautionary principle, which nudges stakeholders and policy-makers alike to respond to identified threats of serious or irreversible damage to the environment or human health, even with the lack of full scientific certainty, by not postponing cost-effective measures that can help prevent or reduce environmental degradation or damage to human health.

\section{CONCLUSION}

Singapore's urban planning experience may not be directly relevant to other cities undergoing rapid and widespread urbanization. But her experience suggests that law and policy can make a difference in urban planning outcomes such as improving liveability and enhancing the sustainability of the built environment. Indeed, the success of sustainable development goals is premised on improvements in governance and the rule of law, which are each framed by supportive legislative frameworks. All these require particular decisions on resource allocation for which the legal system can provide a framework but the law cannot endow urban planning with the values desired by a society.

The Singapore experience also highlights the importance of policy and legislative implementation. The best of urban planning ideas can only materialize if there is effective and efficient implementation. Notwithstanding this caveat, the role of law and policy is certainly under studied and offers prospects for a better understanding of the urban planning experience and outcomes. In a post-COVID world, urban planning will also be transformed.

46 That social justice should not be excluded from urban policy, see Fainstein S. (2010), The Just City, Ithaca, NY: Cornell University Press. On 'future-proofing' cities by balancing economic growth with human values in the urban landscape, see Economist Intelligence Unit (2015), Tomorrow's Cities: Creating Optimal Environments for Citizens, IESE Center for Globalization and Strategy (2015), IESE Cities in Motion Index 2015, and Arcadis (2015), Sustainable Cities Index 2015: Balancing the Economic, Social and Environmental Needs of the World's Leading Cities. 
How a densely-populated Singapore navigates the vagaries of an uncertain world posed by public health concerns will be another challenge urban planners will have to take the bull by its horns.

\section{References}

[1] Arcadis (2015), Sustainable Cities Index 2015: Balancing the Economic, Social and Environmental Needs of the World's Leading Cities. Retrieved from https://www.arcadis.com/media/E/F/B/\%7BEFB74BBBD788-42EF-A761-4807D69B6F70\%7D9185R_Arcadis_whitepaper_2015.pdf [accessed 2 June 2020]

[2] Bell D. A. \& de Shalet A. (2011), The Spirit of Cities: Why the Identity of a City Matters in a Global Age. Princeton, NJ: Princeton University Press

[3] Buckley C. B. (1984), An Anecdotal History of Old Times in Singapore: From the Foundation of the Settlement on February $6^{\text {th }}$, 1819 to the Transfer to the Colonial Office on April 1 ${ }^{\text {st }}, 1867$, Singapore: Oxford University Press

[4] Chang J-H \& Winter T. (2015), 'Thermal Modernity and Architecture', The Journal of Architecture, Vol. 20, pp. 92-121

[5] Chua B-H (1997), Political Legitimacy and Housing: Stakeholding in Singapore, London, Routledge

[6] Daalder I. (2015), 'An International Order of Cities Not States', Financial Times, 27 May 2015, p. 7

[7] Dale O. J. (1999), Urban Planning in Singapore: The Transformation of a City, Shah Alam: Oxford University Press

[8] Dobbs R. (2015), 'The four global forces breaking all the trends', McKinsey Quarterly, April 2015

[9] Economist Intelligence Unit (2015), Tomorrow's Cities: Creating Optimal Environments for Citizens

[10] Fainstein S. (2010), The Just City, Ithaca, NY: Cornell University Press

[11] Guo R. (2018), Urban Redevelopment: From Urban Squalor to Global City, Singapore: Centre for Liveable Cities. Retrieved from https://www.clc.gov.sg/docs/default-source/urban-systemsstudies/uss-urbanredevelopment.pdf [accessed 2 June 2020]

[12] Han F. K. et al. (eds.) (1998), Lee Kuan Yew: The Man and His Ideas, Singapore: Times Editions

[13] Henderson J. C. (2013), 'Urban Parks and Green Spaces in Singapore', Managing Leisure, Vol. 18, pp. 213-225

[14] Heng C. K. \& Low B. L. (2009) 'New Asian Public Space: Layered Singapore,' 14 Urban Design International 231-246

[15] Hill M. \& Lian K. F. (1995), The Politics of Nation Building and Citizenship in Singapore, London: Routledge

[16] HistorySG (n.d.), 'Land Acquisition Act is Enforced (17 June 1967)'Cities. Retrieved from http:// eresources.nlb.gov.sg/history/events/1f669eff-bc82-49d1-a27c-2624e4cab8c6 [accessed 2 June 2020]

[17] IESE Center for Globalization and Strategy (2015), IESE Cities in Motion Index 2015

[18] Khoo L-M. (2018), Engaging Well, Forging Bonds: The Community as Stakeholders in Urban Development. Singapore: Centre for Liveable Cities. Retrieved from https://www.clc.gov.sg/docs/defaultsource/urban-systems-studies/uss-engaging-well-website.pdf [accessed 2 June 2020]

[19] Khoo T. C. (ed.) (2014), Land Acquisition and Resettlement: Securing Resources for Development, Singapore: Centre for Liveable Cities. Retrieved from https://www.clc.gov.sg/docs/defaultsource/urban-systems-studies/uss-land-acquisition-and-resettlement.pdf [accessed 2 June 2020]

[20] Khoo T. C. (ed.) (2014), Financing a City: Developing Foundations for Sustainable Growth, Singapore: Centre for Liveable Cities. Retrieved from https://www.clc.gov.sg/docs/default-source/urbansystems-studies/uss-financing-a-city.pdf [accessed 2 June 2020]

[21] Khublall N. \& Yuen B. (1991), Development Control and Planning Law in Singapore, Singapore: Longman Singapore

[22] Koolhaas R. (1995), 'The Singapore Songlines - Portrait of a Potemkin Metropolis' in Koolhaas R. and Mau B., edited by Sigler J. (1995), Small, Medium, Large, Extra-Large: Office for Metropolitan Architecture, Rotterdam: O10 Publishers

[23] Kwek M. L. (2004) 'Singapore: A Skyline of Pragmatism', in Bishop, R. et al. (eds.), Beyond Description: Singapore Space Historicity. London: Routledge 
[24] Kwek S. C. (2019), Resettling Communities: Creating Space for Nation Building, Singapore: Centre for Liveable Cities. Retrieved from https://www.clc.gov.sg/docs/default-source/urban-systemsstudies/uss-resettling-communities.pdf [accessed 2 June 2020]

[25] Lai A. E. (1995), Meanings of Multiethnicity: A Case Study of Ethnicity and Ethnic Relations in Singapore, Kuala Lumpur: Oxford University Press

[26] Lee H. L. (2014), Speech by Prime Minister of Singapore at the official opening of the Jurong Rock Caverns on 2 September 2014. Retrieved from http://www.pmo.gov.sg/media-release/ transcript-prime-minister-lee-hsien-loongs-speech-official-opening-jurong-rock-caverns [accessed 2 June 2020]

[27] Leon J. K. (2015), 'The Role of Global Cities in Land Grabs', Third World Quarterly, Vol. 36, pp. 257-273

[28] Lim E.-B. (2014), 'Future Island', Third Text, Vol. 28, pp. 443-453

[29] Melic K. (2019), Past, Present and Future: Conserving the Nation's Built Heritage, Singapore: Centre for Liveable Cities. Retrieved from https://www.clc.gov.sg/docs/default-source/urban-systemsstudies/uss-conserving-the-nations-built-heritage.pdf [accessed 2 June 2020]

[30] National Population and Talent Division (2013), Population White Paper: A Sustainable Population for a Dynamic Singapore. Retrieved from http://www.nptd.gov.sg/content/NPTD/news/_jcr_ content/par_content/download_98/file.res/population-white-paper.pdf [accessed 2 June 2020]

[31] Ng M. F. C. (2012), Habitats in Harmony: The Story of Semakau Landfill, $2^{\text {nd }}$ edition, Singapore: National Environment Agency

[32] Ng M. \& Choy, C. P. (2018), Land Framework of Singapore: Building a Sound Land Administration and Management System, Singapore: Centre for Liveable Cities. Retrieved from https://www.clc. gov.sg/docs/default-source/urban-systems-studies/uss-land-framework-of-singapore.pdf [accessed 2 June 2020]

[33] Ooi G. L. (2004), Future of Space: Planning, Space and the City, Singapore: Eastern Universities Press

[34] Phang S. Y. (1996), 'Economic Development and the Distribution of Land Rents in Singapore: A Georgist Implementation', The American J. of Economics and Sociology, Vol. 55, pp. 489-501

[35] Rodan G. (1996), 'Elections Without Representation: The Singapore Experience under the PAP', in Taylor R. H. (ed.), The Politics of Elections in Southeast Asia, New York: Cambridge University Press

[36] Schein E. H. (1996), Strategic Pragmatism: The Culture of Singapore's Economic Development Board. Cambridge, MA: MIT Press

[37] Singapore Parliament Reports, various volumes

[38] Statutes of the Republic of Singapore, Land Acquisition Act, Cap. 152 (1985 Revised Edition), and Planning Act Cap. 232 (1998 Revised Edition)

[39] Tan. B. \& Zhou. Y. (2018), Technology and the City: Foundation for a Smart Nation, Singapore: Centre for Liveable Cities. Retrieved from https://www.clc.gov.sg/docs/default-source/urban-systemsstudies/uss-technology-and-the-city.pdf [accessed 2 June 2020]

[40] Tan S. (1999), Home, Work, Play. Singapore: Urban Redevelopment Authority

[41] Toh E. \& Ee D. (2019), Rule of Law and Urban Development. Singapore: Centre for Liveable Cities

[42] Wong G. K. M. (2004), 'Vertical Cities as a Solution for Land Scarcity: The Tallest Public Housing Development in Singapore', Urban Design International, Vol. 9, pp. 17-30

[43] Wong T-C., \& Yap L-H A. (2004), Four Decades of Transformation: Land Use in Singapore, 19602000, Singapore: Eastern University Press

[44] World Economic Forum (2020), 'To stop the spread of diseases like the coronavirus, we need to reinvent our cities', 20 February. Retrieved from https://www.weforum.org/agenda/2020/02/ deadly-disease-outbreaks-city-planners [accessed 2 June 2020]

[45] Wu W.N. \& Chia J. (2017), Working with Markets: Harnessing Market Forces and Private Sector for Development, Singapore: Centre for Liveable Cities. Retrieved from https://www.clc.gov.sg/docs/ default-source/urban-systems-studies/working-with-markets.pdf [accessed 2 June 2020]

[46] Yang W. \& Kuang J. Y. (2020), Water: From Scarce Resource to National Asset, Singapore: Centre for Liveable Cities. Retrieved from https://www.clc.gov.sg/docs/default-source/urban-systemsstudies/uss-water-revised.pdf [accessed 2 June 2020]

[47] Yuen B. (ed.) (1998), Planning Singapore: From Plan to Implementation. Singapore: Singapore Institute of Planners 